\title{
Evidence of a new ordered vacancy crystal structure in the compound $\mathrm{Cu}_{3} \mathrm{In}_{7} \mathrm{Te}_{12}$
} Gerzon E. Delgado ${ }^{1}$, Edicson Guedez $^{2}$,
Gerardo Sanchéz-Pérez ${ }^{2}$, Carlos Rincón ${ }^{2}$ Gustavo Marroquin ${ }^{3}$

\author{
${ }^{1}$ Laboratorio de Cristalografía, Departamento de Química, Facultad de Ciencias, Universidad de Los Andes, Mérida, \\ Mérida, Venezuela. \\ ${ }^{2}$ Centro de Estudios de Semiconductores, Departamento de Física, Facultad de Ciencias, Universidad de Los Andes, \\ Mérida, Mérida, Venezuela. \\ ${ }^{3}$ Escuela Superior de Ingeniería Química e Industrias Extractivas, Instituto Politécnico Nacional, Zacatenco, Ciudad de \\ México, México. \\ e-mail: gerzon@ula.ve,eguedez24@gmail.com,gerardop1109@gmail.com,crincon@ula.ve,gmarroqui@hotmail.com
}

\section{ABSTRACT}

The crystal structure of the ordered vacancy compound (OVC) $\mathrm{Cu}_{3} \mathrm{In}_{7} \mathrm{Te}_{12}$ is analyzed using powder X-ray diffraction data. It is found that this OVC crystallizes with a chalcopyrite-related structure, in the tetragonal space group $P \overline{4} 2 c\left(\mathrm{~N}^{\circ} 112\right)$, with unit cell parameters and volume $a=6.1720(2) \AA, c=12.3597(8) \AA$, and $\mathrm{V}$ $=470.83(4) \AA^{3}$. The Rietveld refinement of 28 instrumental and structural parameters led to $R_{p}=9.27 \%, R_{w p}$ $=10.30 \%, R_{\exp }=6.95 \%$ and $\mathrm{S}=1.48$, for 4501 step intensities and 130 independent reflections, respectively. This compound is isostructural with $\mathrm{Cu}_{3} \mathrm{In}_{7} \mathrm{Se}_{12}$, and has a defect adamantane structure.

Keywords: semiconductors, ordered vacancy compounds, crystal structure, X-ray diffraction, Rietveld.

\section{INTRODUCTION}

The ternary compound $\mathrm{CuInTe}$, belonging to the I-III- $-\mathrm{VI}_{2}$ family of chalcopyrite semiconductors, crystallize in the tetragonal space group $I \overline{4} 2 d$ with unit cell parameters $a=6.1944(20)$ and $c=12.4157(40) \AA$ [1]. This material has been found to be a suitable material for thermoelectric (TE) applications [2-5]. Hence, it is also expected that ordered vacancy compounds (OVC's) of the Cu-In-Te system [6], which can be described as normal tetrahedral structures with a certain fixed number of unoccupied structure sites [7] and can be generated through the formula $\mathrm{Cu}_{n-3} \mathrm{In}_{n+1} \mathrm{Te}_{2 n}$, such as $\mathrm{CuIn}_{5} \mathrm{Te}_{8}(n=4), \mathrm{CuIn}_{3} \mathrm{Te}_{5}(n=5), \mathrm{Cu}_{3} \operatorname{In}_{7} \mathrm{Te}_{12}(n=6)$, $\mathrm{Cu}_{5} \mathrm{In}_{9} \mathrm{Te}_{16}(n=8)$, and $\mathrm{Cu}_{3} \mathrm{In}_{5} \mathrm{Te}_{9}(n=9)$ [8], could also be employed for TE applications [9]. This is because most of them have low carrier concentrations [10], a tetragonal distortion parameter $\eta(\eta=c / 2 a)$ close to unity [6], and also an energy gap less than about $1.2 \mathrm{eV} \mathrm{[11],} \mathrm{which} \mathrm{are} \mathrm{some} \mathrm{of} \mathrm{the} \mathrm{conditions} \mathrm{required} \mathrm{to}$ achieve promising materials for TE applications [2]. As regard to the crystal structure of these $\mathrm{Cu}-\mathrm{In}-\mathrm{Te}$ OVC's, although it has been suggested that most of them crystallize in tetragonal chalcopyrite-related structures [4,10,12-14], their actual crystal structures and corresponding space groups have not yet been established, as evidenced by a search in the Inorganic Crystal Structure Database (ICSD) [15].

Hence, in the present work, the crystal structure of $\mathrm{Cu}_{3} \mathrm{In}_{7} \mathrm{Te}_{12}$ (or $\mathrm{Cu}_{3} \mathrm{In}_{7}[]_{2} \mathrm{Te}_{12}$, where [] represents the cationic vacancy) is established from the Rietveld refinement analysis of powder X-ray diffraction data.

\section{MATERIALS AND METHODS}

Polycrystalline samples of $\mathrm{Cu}_{3} \mathrm{In}_{7} \mathrm{Te}_{12}$ used in this study were prepared from the melt by the vertical Bridgman-Stockbarger technique in a multiple zone furnace. Stoichiometric mixture of highly pure components of $\mathrm{Cu}$, In and Te (99.999\%) were introduced in a quartz ampoule sealed under vacuum $\left(\sim 10^{-3} \mathrm{~Pa}\right)$. Initially, the ampoule was heated from room temperature to $1170 \mathrm{~K}$ at a rate of $20 \mathrm{~K} / \mathrm{h}$. The molten mixture was then heated to $1370 \mathrm{~K}$ at $10 \mathrm{~K} / \mathrm{h}$ and kept at this temperature for $12 \mathrm{~h}$. To assure a homogeneous mixing of the melt, the ampoule was carefully agitated periodically. It was later cooled at $10 \mathrm{~K} / \mathrm{h}$ to $1090 \mathrm{~K}$, and at $5 \mathrm{~K} / \mathrm{h}$ to $800 \mathrm{~K}$. In order to guarantee the equilibrium condition of the synthetized material, the ingot was annealed at 
this temperature for $120 \mathrm{~h}$. The furnace was then turned off and the ingot cooled down to the room temperature.

For the X-ray diffraction analysis, a small quantity of the sample, cut from the ingot, was ground mechanically in an agate mortar and pestle. The resulting fine powder was mounted on a flat zero-background holder covered with a thin layer of petroleum jelly. The powder X-ray diffraction data was collected at 293(1) $\mathrm{K}$, in $\theta / \theta$ reflection mode using a Siemens D5005 diffractometer equipped with an X-ray tube (CuKa radiation: $\lambda=1.5418 \AA ; 40 \mathrm{kV}, 30 \mathrm{~mA})$. A fixed aperture and divergence slit of $1 \mathrm{~mm}$, a $1 \mathrm{~mm}$ monochromator slit, and a $0.1 \mathrm{~mm}$ detector slit, were used. The specimen was scanned from $10^{\circ}-100^{\circ} 2 \theta$, with a step size of $0.02^{\circ}$ and counting time of $10 \mathrm{~s}$. Quartz was used as an external standard. The Bruker AXS analytical software was used to establish the positions of the peaks.

\section{RESULTS AND DISCUSSION}

Figure 1 shows the resulting powder X-ray diffractogram for $\mathrm{Cu}_{3} \mathrm{In}_{7} \mathrm{Te}_{12}$. The 20 first peak positions were indexed using the program Dicvol04 [16], which gave a unique solution in a tetragonal cell. Lack of systematic absences $(h k l: h+k+l)$, indicates a primitive type lattice. In addition, the condition $h h l: l=2 n+1$ suggests the extension symbol $P \overline{4} 2 c$. A revision of the diffraction lines, taking into account the sample composition, unit cell parameters, and lattice-type, suggests that this material is isostructural with $\mathrm{Cu}_{3} \mathrm{In}_{7} \mathrm{Se}_{12}$. This is the first compound with the $\mathrm{I}_{3}-\mathrm{III}_{7}-[]_{2}-\mathrm{VI}_{12}$ formula which has been reported to crystallize in a tetragonal structure with space group $P \overline{4} 2 c\left(\mathrm{~N}^{\circ} 112\right)$ [17]. The resulting X-ray powder diffraction data for $\mathrm{Cu}_{3} \mathrm{In}_{7} \mathrm{Te}_{12}$ will be submitted to the Powder Diffraction File of the International Centre for Diffraction Data (ICDD) [18].

The Rietveld refinement [19] of the whole diffraction pattern was carried out using the Fullprof program [20, 21], with the unit cell parameters found in the indexing. For the refinement of $\mathrm{Cu}_{3} \operatorname{In}_{7} \mathrm{Te}_{12}$, the atomic coordinates of the compound $\mathrm{Cu}_{3} \mathrm{In}_{7} \mathrm{Se}_{12}$ [17], were used as initial model, with the cation distribution shown in Table III. The angular dependence of the peak full width at half maximum (FWHM), was described by the Cagliotti's formula [22]. Peak shapes were described by the parameterized Thompson-Cox-Hastings pseudo-Voigt profile function [23]. The background variation was described by a polynomial with six coefficients. The thermal motion of the atoms was described by one overall isotropic temperature factor.

The results of the Rietveld refinement are summarized in Table 1. Figure 1 shows the observed, calculated, and difference profile for the final cycle of refinement. Atomic coordinates, isotropic temperature factor, bond distances, and angles are shown in Table 2. This Table also shows the Bond Valence Sum (BVS) $[24,25]$ results for $\mathrm{Cu}_{3} \mathrm{In}_{7} \mathrm{Te}_{12}$, indicating that the oxidation state for each ion is in good agreement with the expected formal oxidation state of $\mathrm{Cu}^{1+}, \mathrm{In}^{3+}$ and $\mathrm{Te}^{2-}$ ions.

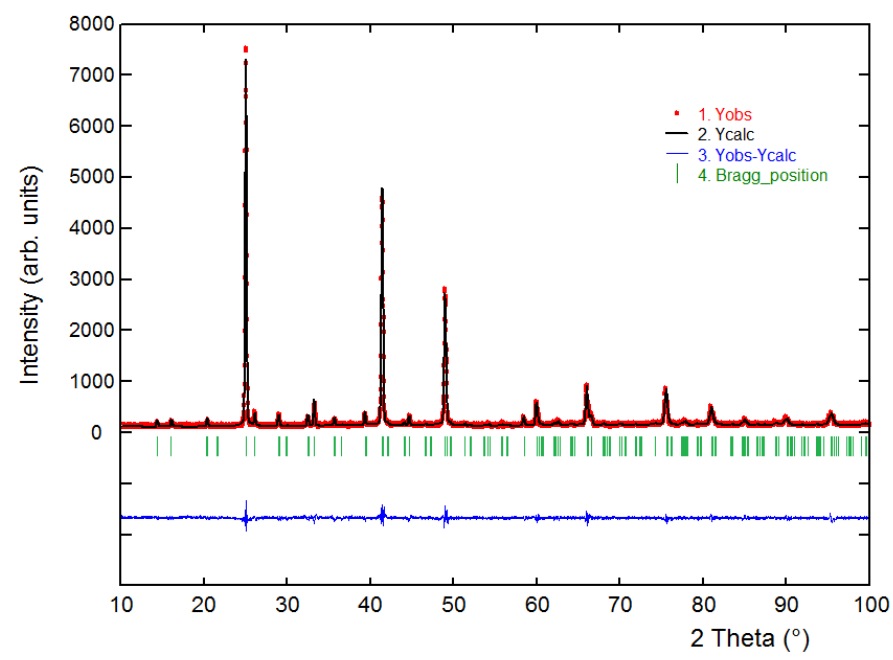

Figure 1: Rietveld refinement plot for $\mathrm{Cu}_{3} \mathrm{In}_{7} \mathrm{Te}_{12}$. The lower trace is the difference curve between observed and calculated patterns. The Bragg reflections are indicated by vertical bars.

From refinement by the Rietveld method by using powder X-ray diffraction data, it has been found that this material crystallizes in the tetragonal space group $P \overline{4} 2 c$, with a chalcopyrite-related structure. This 
consists of a three-dimensional arrangement of distorted $\mathrm{CuTe}_{4}$ and $\mathrm{InTe}_{4}$ tetrahedra connected by common faces. In this structure, each Te atom is coordinated by four cations (one $\mathrm{Cu}$ and three $\mathrm{In}$ ) located at the corners of a slightly distorted tetrahedron. In the same way, each cation is tetrahedrally bonded to four anions. This array is expected for adamantane compounds [7].

The $\mathrm{Cu}$-Te and In-Te bond distances for $\mathrm{Cu}_{3} \mathrm{In}_{7} \mathrm{Te}_{12}$ here obtained, are in good agreement with those reported in the ICSD database [15] for other adamantane structure compounds such as CuInTe ${ }_{2}$ [26], $\mathrm{AgIn}_{5} \mathrm{Te}_{8}$ [27], $\mathrm{CuTa}_{2} \mathrm{InTe}_{4}$ [28], $\mathrm{Cu}_{3} \mathrm{NbTe}_{4}$ [29], AgInTe 2 [1] and $\mathrm{CuCo}_{2} \mathrm{InTe}_{4}$ and $\mathrm{CuNi}_{2} \mathrm{InTe}_{4}$ [30].

Table 1: Rietveld refinement results for $\mathrm{Cu}_{3} \mathrm{In}_{7} \mathrm{Te}_{12}$.

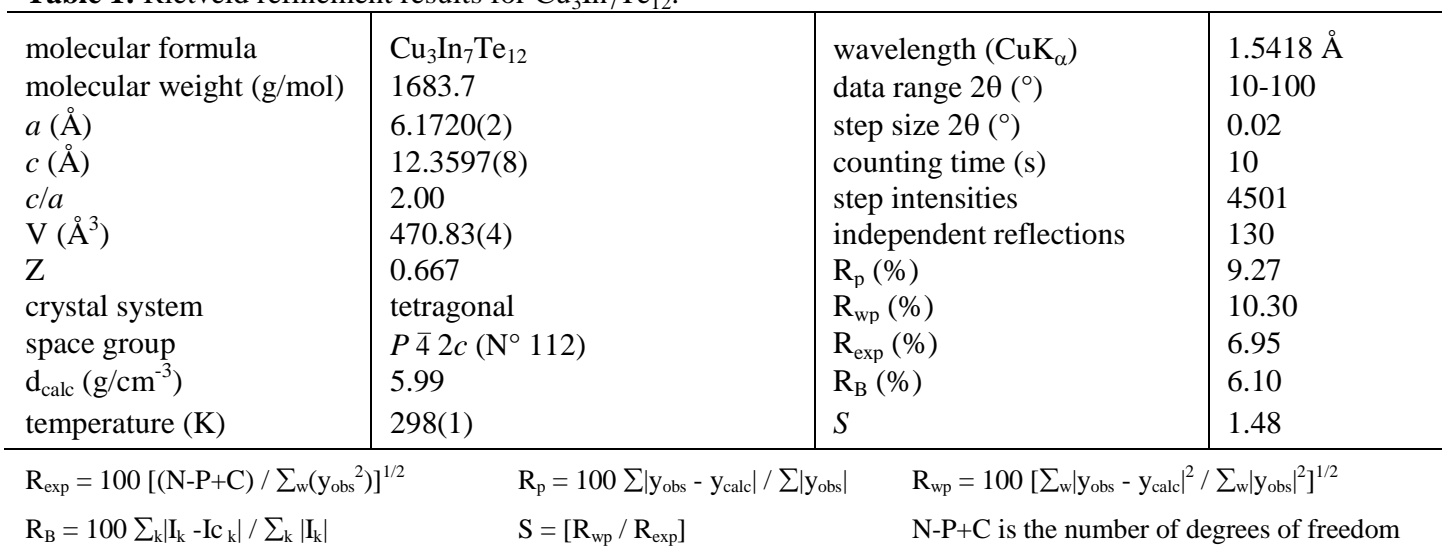

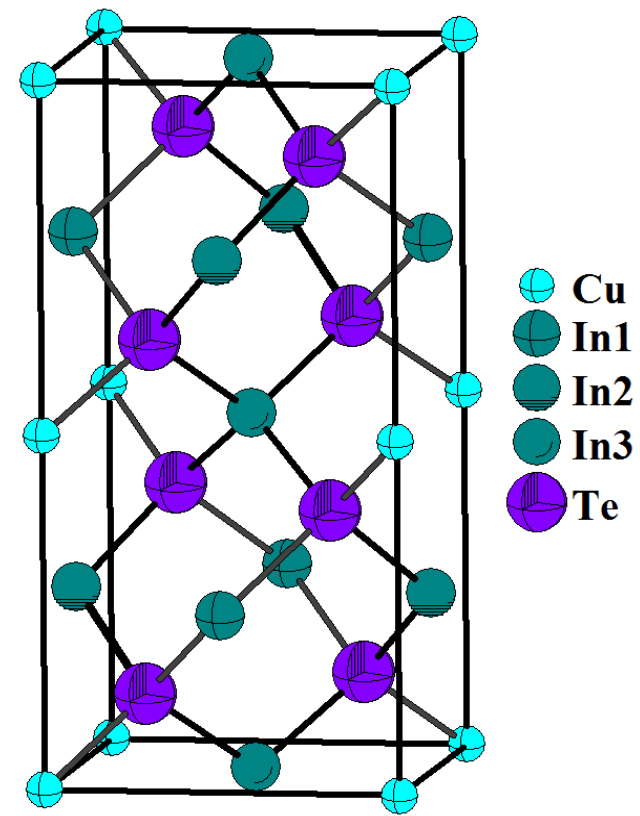

Figure 2: Unit cell diagram for the ordered vacancy compound $\mathrm{Cu}_{3} \mathrm{In}_{7} \mathrm{Te}_{12}$. 
Table 2: Atomic coordinates, isotropic temperature factors, bond distances $(\AA)$ and angles $\left(^{\circ}\right)$ for $\mathrm{Cu}_{3} \mathrm{In}_{7} \mathrm{Te}_{12}$, derived from the Rietveld refinement. Bond valence sum (BVS) are also showed.

\begin{tabular}{ccccccccc}
\hline \hline Atom & Ox. & BVS & Site & $\boldsymbol{x}$ & $\boldsymbol{y}$ & $\boldsymbol{z}$ & foc & $\mathbf{B}\left(\AA^{2}\right)$ \\
\hline $\mathrm{Cu}$ & +1 & 1.3 & $2 e$ & 0 & 0 & 0 & 1 & $0.4(3)$ \\
{[]} & & & $2 a$ & 0 & 0 & $1 / 4$ & 1 & \\
$\mathrm{In} 1$ & & & $2 b$ & $1 / 2$ & 0 & $1 / 4$ & 1 & $0.4(3)$ \\
$\mathrm{In} 2$ & +3 & 3.3 & $2 d$ & 0 & $1 / 2$ & $1 / 4$ & 1 & $0.4(3)$ \\
$\mathrm{In} 3$ & & & $2 f$ & $1 / 2$ & $1 / 2$ & 0 & $1 / 3$ & $0.4(3)$ \\
$\mathrm{Te}$ & -2 & 2.4 & $8 n$ & $0.223(1)$ & $0.261(1)$ & $0.118(1)$ & 1 & $0.4(3)$ \\
\hline $\mathrm{Cu}-\mathrm{Se}^{i}$ & $2.572(9)$ & & In1-Te & $2.860(9)$ & In2- $\mathrm{Te}^{i i}$ & $2.595(9)$ & $\operatorname{In}^{i i}-\mathrm{Te}^{i v}$ & $2.688(9)$ \\
\hline \hline
\end{tabular}

Symmetry codes: ${ }^{\text {(i) }} \mathrm{y},-\mathrm{x},-\mathrm{z} ;{ }^{\text {(ii) }} 1-\mathrm{x}, 1-\mathrm{y}, \mathrm{z} ;{ }^{\text {(iii) }} \mathrm{x},-\mathrm{y}, 0.5-\mathrm{z} ;{ }^{\text {(iv) }}-\mathrm{x}, \mathrm{y}, 0.5-\mathrm{z}$.

Bond valence sum $(B V S): V_{i}=\sum_{j} \exp \left[\left(R_{0}-R_{i j}\right) / b\right], b=0.37 \AA, r_{o}(C u-T e)=2.27 \AA,(I n-T e)=2.69 \AA$

\section{CONCLUSIONS}

In conclusion, it is established that the ordered vacancy compound $\mathrm{Cu}_{3} \mathrm{In}_{7} \mathrm{Te}_{12}\left(\right.$ or $\left.\mathrm{Cu}_{3} \mathrm{In}_{72} \mathrm{Te}_{12}\right)$ crystallizes with a chalcopyrite-related structure in the tetragonal space group $P 42 c$, and represents a new semiconductor with formula $\mathrm{I}_{3}-\mathrm{III}_{7}-[]_{2}-\mathrm{VI}_{12}$.

\section{ACKNOWLEDGMENTS}

This work was supported by CDCHTA-ULA and FONACIT (Grant LAB-97000821).

\section{BIBLIOGRAPHY}

[1] KNIGHT, K. S., "The crystal structures of CuInSe 2 and CuInTe", Materials Research Bulletin, v. 27, n. 2, pp. 161-167, Feb. 1992.

[2] ZHANG, J., LIU, R., CHENG, N., et al., "High-performance pseudocubic thermoelectric materials from non-cubic chalcopyrite compounds", Advanced Materials, v. 26, n. 23, pp. 3848-3853, Jun. 2014.

[3] ZHOU, G., WANG, D., "High thermoelectric performance from optimization of hole-doped CuInTe 2 ". Physical Chemistry Chemical Physics, v. 18, n. 11, pp. 5925-5931, Nov. 2016.

[4] PLIRDPRING, T., KUROSAKI, K., KOSUGA, A., et al., "High-temperature thermoelectric properties of $\mathrm{Cu}_{2} \mathrm{In}_{4} \mathrm{Te}_{7}$, , Physica Status Solidi rapid research letters, v. 6, n. 4, pp. 154-156, April 2012.

[5] PLIRDPRING, T., KUROSAKI, K., KOSUGA, A., et al., "High-temperature thermoelectric properties of $\mathrm{Cu}_{3} \mathrm{In}_{5} \mathrm{Te}_{9}$ with defect-chalcopyrite structure", Advances Science Letters, v. 19, n. 1, pp. 183-185, Jan. 2013.

[6] RINCÓN, C., WASIM, S. M, MARÍN, G., "Scattering of the charge carriers by ordered arrays of defect pairs in ternary chalcopyrite semiconductors", Applied Physics Letters, v. 80, n. 6, pp. 998-1000, Feb. 2002.

[7] PARTHÉ, E. "Intermetallic compounds, principles and applications", Chichester, UK: John Wiley \& Sons, 1995.

[8] ZHANG S. B., WEI S-H., ZUNGER A., "Stabilization of Ternary Compounds via Ordered Arrays of Defect Pairs", Physical Review Letters v. 80, n. 21, pp. 4059-4062, May 1997.

[9] KOSUGA, A., HIGHASINE, R., PLIRDPRING, T., et al., "Effects of the defects on the thermoelectric properties of $\mathrm{Cu}-\mathrm{In}$-Te chalcopyrite-related compounds", Japanese Journal of Applied Physics, v. 51, n. 12R, pp. 121803, Nov. 2012.

[10] RINCÓN, C., WASIM, S. M, MARÍN, G., et al., "Effect of ordered arrays of native defects on the crystal structure of In-and Ga-rich Cu-ternaries”, Applied Physics Letters, v. 83, n. 7, pp. 1328-1330, Aug. 2003.

[11] WASIM, S. M, RINCÓN, C., MARÍN, G., et al., "On the band gap anomaly in I-III-VI $\mathrm{VI}_{2}, \mathrm{III}_{3}-\mathrm{VI}_{5}$, and I-III ${ }^{-}-\mathrm{VI}_{8}$ families of Cu ternaries”, Applied Physics Letters, v. 77, n. 1, pp. 94-96, Jul. 2000.

[12] PARLAK, M., ERCELEBI, C., GUNAL I., et al., "Crystal Data, Electrical Resisitivity and Mobility in 
$\mathrm{Cu}_{3} \mathrm{In}_{5} \mathrm{Se}_{9}$ and $\mathrm{Cu}_{3} \mathrm{In}_{5} \mathrm{Te}_{9}$ Single Crystals" Crystal Research and Technology, v. 32, n. 3, pp. 395-400, Jan 1997.

[13] GUEDEZ, E., MOGOLLÓN, L., MARCANO, et al., "Structural characterization and optical absorption spectrum of $\mathrm{Cu}_{3} \mathrm{In}_{5} \mathrm{Te}_{9}$ ", Materials Letters, v. 186, pp. 155-157, Jan. 2017.

[14] DÍAZ, R., BISSON, L., AGULLÓ-RUEDA F., et al., "Effect of composition gradient on $\mathrm{CuIn}_{3} \mathrm{Te}_{5}$ single-crystal properties and micro-Raman and infrared spectroscopies", Applied Physics A, v. 81, pp. 433-438, April 2005.

[15] ICSD-Inorganic Crystal Structure Database, Gemlin Institute, Kalrsruhe, Germany, 2016.

[16] BOULTIF, A., LÖUER, D., "Powder pattern indexing with the dichotomy method", Journal of Applied Crystallography, v. 37, n. 5, pp. 724-731, Oct. 2004.

[17] DELGADO, G. E., MANFREDY, L., LÓPEZ-RIVERA, S. A., "Crystal structure of the ternary semiconductor Cu2In14/3 $\square$ 4/3Se8 determined by X-ray powder diffraction data", Powder Diffraction, v. 33, n. 3, pp. 237-241, Oct. 2018.

[18] PDF-Powder Diffraction File (set 1-65), International Centre for Diffraction Data, Newtown Square, PA, USA, 2013.

[19] RIETVELD, H. M., "A profile refinement method for nuclear and magnetic structures", Journal of Applied Crystallography, v. 2, n. 2, pp. 65-71, Feb. 1969.

[20] RODRÍGUEZ-CARVAJAL, J., "Recent advances in magnetic structure determination by neutron powder diffraction", Physica B, v. 192, n. 1-2, pp. 55-69, Oct. 1993.

[21] RODRÍGUEZ-CARVAJAL, J., "Fullprof”, version 5.8, LLB, CEA-CNRS, France, 2016.

[22] CAGLIOTTI, G., PAOLETTI, A., RICCI, F. P., "Choice of collimators for a crystal spectrometer for neutron diffraction". Nuclear Instruments, v. 3, n. 4, 223-228, Oct. 1958.

[23] THOMPSON, P., COX, D. E., HASTINGS, J. B., "Rietveld refinement of Debye-Scherrer synchrotron X-ray data from $\mathrm{Al}_{2} \mathrm{O}_{3}$ ”, Journal of Applied Crystallography, v. 20, n. 2, pp. 79-83, Apr. 1987.

[24] BROWN, I. D., ALTERMATT, D., "Bond-valence parameters obtained from a systematic analysis of the inorganic crystal structure database". Acta Crystallographica B, v. 41, n. 4, pp. 244-247, Aug. 1985.

[25] BRESE, N. E., O'KEEFFE, M., "Bond-valence parameters for solids", Acta Crystallographica B, v. 47, n. 2, pp. 192-197, Apr. 1991.

[26] MORA, A. J., DELGADO, G. E., PINEDA, C., et al., "Synthesis and structural study of the $\mathrm{AgIn}_{5} \mathrm{Te}_{8}$ compound by X-ray powder diffraction”, Physica Status Solidi A, v. 201, n. 7, pp. 1477-1483, May. 2004.

[27] DELGADO, G. E., MORA, A. J., GRIMA-GALLARDO, P., et al., "Crystal structure of the quaternary compound $\mathrm{CuTa}_{2} \mathrm{InTe}_{4}$ from X-ray powder diffraction", Physica B, v. 403, n. 18, pp. 3228-3230, Sep. 2008.

[28] DELGADO, G. E., MORA, A. J., GRIMA-GALLARDO, P., et al., "Synthesis and characterization of the ternary chalcogenide compound $\mathrm{Cu}_{3} \mathrm{NbTe}_{4}$ ", Chalcogenide Letters, v. 6, n. 8, pp. 335-338, Aug. 2009

[29] DELGADO, G. E., MORA, A. J., PINEDA, C., et al., "X-ray powder diffraction data and rietveld refinement of the ternary semiconductor chalcogenides $\mathrm{AgInSe}_{2}$ and $\mathrm{AgInTe}_{2}$ ", Revista Latinoamericana de Metalurgia y Materiales, v. 35, n. 1, pp. 110-117, Mar. 2015.

[30] DELGADO, G. E., GRIMA-GALLARDO, P., NIEVES, L., et al., "Structural characterization of two new quaternary chalcogenides: $\mathrm{CuCo}_{2} \mathrm{InTe}_{4}$ and $\mathrm{CuNi}_{2} \mathrm{InTe}_{4}$ ", Materials Research, v. 19, n. 6, pp. 14231428, Dec. 2016.

\section{ORCID}

Gerzon E. Delgado

Edicson Guedez

Carlos Rincón

Gustavo Marroquin

Gerardo Sanchez-Perez http://orcid.org/0000-0003-3970-2387

http://orcid.org/0000-0002-2493-8680

http://orcid.org/0000-0001-5478-2421

https://orcid.org/0000-0001-7887-3416

https://orcid.org/0000-0003-0967-5824 